\title{
ASSESSMENT OF RETENTION POTENTIAL AND SOIL ORGANIC CARBON DENSITY OF AGRICULTURALLY USED CHERNOZEMS, CAMBISOLS AND FLUVISOLS
}

\author{
Martin Brtnický ${ }^{1,2}$, Václav Pecina ${ }^{1}$, Tereza Dokulilová ${ }^{1}$, Jan Vopravil ${ }^{3}$, \\ Tomáš Khel ${ }^{3}$, Jan Zloch ${ }^{1}$, Vítězslav Vlček ${ }^{2}$
}

\footnotetext{
${ }^{1}$ Department of Geology and Pedology, Faculty of Forestry and Wood Technology, Mendel University in Brno, Zemědělská 1, 61300 Brno, Czech Republic

${ }^{2}$ Department of Agrochemistry, Soil Science, Microbiology and Plant Nutrition, Faculty of AgriSciences, Mendel University in Brno, Zemědělská 1, 61300 Brno, Czech Republic

${ }^{3}$ Research Institute for Soil and Water Conservation, Žabovřeská 250, 15627 Praha, Czech Republic
}

To link to this article: https://doi.org/10.11118/actaun201967051131

Received: 25. 7. 2019, Accepted: 4. 9. 2019

To cite this article: BRTNICKÝ MARTIN, PECINA VÁCLAV, DOKULILOVÁ TEREZA, VOPRAVIL JAN, KHEL TOMÁŠ, ZLOCH JAN, VLČEK VÍTĚZSLAV. 2019. Assessment of Retention Potential and Soil Organic Carbon Density of Agriculturally used Chernozems, Cambisols and Fluvisols. Acta Universitatis Agriculturae et Silviculturae Mendelianae Brunensis, 67(5): 1131-1137.

\begin{abstract}
Climate change and the increasing frequency of climatic extremes have led to growing concerns over the sustainability of agriculture during recent years. In this context, soil retention and carbon storage are becoming widely discussed. The aim of this study was to evaluate the retention potential (RP) and soil organic carbon density (SOCD) of Chernozem, Cambisol and Fluvisol topsoil under agricultural management. Despite the different natural assumptions of these soil types, no significant statistical difference was found there. Mean RP values of the soil types varied from 39 to $40 \mathrm{~mm}$ and mean SOCD values from 23 to $28 \mathrm{t} / \mathrm{ha}$. This finding may suggest that long-term agricultural management can suppress the naturally diverse potential for water retention and carbon storage of the individual soil types. Comparison of SOCD of the studied soils with agricultural soils in similar studies showed that most of the observed values can be considered as average. Despite this fact, a very strong local degradation has been revealed indicating poor agricultural management. Especially in such cases, there is an urgent need to adjust the management of the agricultural land fund (e.g. increased application of organic fertilizers, change in crop rotation) in order to increase carbon stocks and to improve the water retention capacity of soils.
\end{abstract}

Keywords: soil retention potential, arable land, climate change, soil organic carbon

\section{INTRODUCTION}

Soils are major reservoir of terrestrial organic carbon, and are important in both, sequestering atmospheric $\mathrm{CO}_{2}$ and emitting $\mathrm{CO}_{2}$ which contributes to the 'greenhouse' effect (Mikhailova et al., 2006; Manojlović et al., 2008). Even small changes in soil organic carbon (SOC) storage can result in large variation in atmospheric $\mathrm{CO}_{2}$ concentration (Xu et al., 2011; Chen et al., 2014; Minasny et al.,
2017). Increasing atmospheric $\mathrm{CO}_{2}$ levels related to anthropogenic forcing are related to periods of extreme drought (Brázdil et al., 2015). In relation to climate change and increased frequency of climatic extremes, there is observed reduced soil moisture content which negatively affects agriculture (Trnka et al., 2015; Štěpánek et al., 2016). Extreme shortterm localized precipitation and possibility of its greater frequency are discussed as well (Hanel 
et al., 2016; Rulfová et al., 2017; Beranová and Kyselý, 2018). The mentioned facts lead to greater interest in soil retention.

The issue of soil retention is abundantly discussed social and scientific topic, mainly in relation to landuse. The interest is focused mainly on arable land. The retention is one of the most significant hydraulic properties of soil as it affects and partly defines the whole ecosystem (Rawls et al., 2003). It belongs to the key parameters for water flow modelling in the landscape and for transport of solute in soils (Batjes, 1996; Wösten et al., 2001; Rubio et al, 2008).

Soil retention largely influences soil management (Rawls et al., 2003) and vice versa (Chen et al., 2015). It is used, for example, in agriculture, hydrology, meteorology, ecology or environmental protection (Rawls et al., 2003). The issue of soil retention, especially in larger areas, is faced with the inherent time and spatial variability. It is necessary to work with a large number of samples there (Pachepsky et al., 2001; Wösten et al., 2001).

Different soil types have different retention potentials (Chen et al., 2015). Focusing more closely on soil properties, water retention is mainly influenced by texture (sand, silt, and clay content), structure (bulk density and porosity), and organic matter content (Hollis et al., 1977; Pachepsky et al., 1996; Pachepsky et al., 2001; Wösten et al., 2001; Otalvaro et al., 2016; Querejeta, 2017).

The soil organic matter content can be influenced by land management practices (Weber et al., 2007; Hagemann et al., 2017; Wong et al., 2017; Kintl et al., 2018). The content and composition of organic matter in the soil affects both, soil structure and adsorption properties (Rawls et al., 2003). For this reason, soil water retention can be easily influenced by changes in soil organic matter, which can be initiated, e.g. by land management (Weber et al., 2007; Ulyett et al., 2014; Elbl et al., 2015; Hagemann et al., 2017) or climate change (Rawls et al., 2003).

In particular, soil water retention can be reduced by intensive agricultural practices (Ulyett et al., 2014). Regular removal of vegetation leads to rapid deterioration of the physical and hydraulic properties of the soil. It is caused mainly due to a sharp decline in infiltration capacity and increase in bulk density associated with a rapid drop in organic matter content (Ulyett et al., 2014; Querejeta, 2017). Such soil degradation can lead, e.g. to higher risk of flooding (Chen et al., 2015; Collentine and Futter, 2018), water erosion (Querejeta, 2017) or reduced agricultural production (Batjes, 1996; Weber et al., 2007; Manojlovic et al., 2008; Ulyett et al., 2014).

Aims of the study were:

1) to determine retention potential (RP) and soil organic carbon density (SOCD) of agricultural topsoil in the Czech Republic (Moravia region);

2) to compare RP and SOCD of Chernozems, Cambisols and Fluvisos;
3) to assess effect of soil organic matter on RP;

4) to propose adjustment of the management on arable land with respect to climate change.

\section{MATERIALS AND METHODS}

\section{Soil Sampling}

All sampling sites are located in Moravia, Czech Republic. There were taken 55 samples from topsoil $(0-10 \mathrm{~cm})$. The topsoil was chosen because effects of agricultural management are usually the greatest on the surface and they decrease with depth (Ogle et al., 2003). Soil samples intended for analysis of physical properties were collected using $100 \mathrm{~cm}^{3}$ soil column cylinders (Kopecký's cylinders) in three replications. Samples for further analyses were put into plastic bags. There were investigated 3 soil types: Cambisol (26 samples), Chernozem (21 samples) and Fluvisol (8 samples). There was taken different number of samples of the particular soil types as it reflects their abundancy within the arable land.

\section{Sample Analysis}

Physical properties (bulk density, porosity, full water capacity) were determined and evaluated using standard methods according to Zbíral et al. (2016). Soil pH was measured in $1 \mathrm{M}$ of $\mathrm{KCl}$ (ISO 10390, 2005). The $\mathrm{C}_{\mathrm{ox}}$ (oxidizable carbon) was determined by means of oxidation using chromosulphuric mixture (ISO 14235,1998) to characterize SOC (Kubát et al., 2004).

\section{Soil Retention Assessment}

Direct soil retention measurement is quite timeconsuming and expensive. Thus, a number of indirect methods to determine soil retention has been developed (Rubio et al., 2008). The methods are based on different soil properties that are measured more easily (Pachepsky et al., 2001). In our study, the soil retention potential (RP, in mm) was calculated on the basis of the formula (Vlček et al., 2012):

$R P=H \times F W C \times(1-S)$,

where $H$ is thickness of the soil layer (mm), FWC full water capacity (\%) and $S$ is soil skeleton estimate (\%) (in agricultural soil is this value close to zero).

\section{SOC Evaluation}

The SOC density (SOCD) (in t/ha) was calculated on the basis of the formula (Chen et al., 2014; Xia et al., 2016; Liu et al., 2018):

SOCD $=S O C \times \rho \times H \times 10^{-1}$,

where SOC is soil organic carbon $(\mathrm{g} / \mathrm{kg}), \rho$ is bulk density $\left(\mathrm{g} / \mathrm{cm}^{3}\right)$ and $\mathrm{H}$ represents thickness of soil horizon (cm). 
I: Soil retention potential (RP) and soil organic carbon density (SOCD) of individual soil types (in 0-10 cm)

\begin{tabular}{|c|c|c|c|c|c|c|c|c|}
\hline \multirow{2}{*}{ Soil type } & \multicolumn{4}{|c|}{$\mathrm{RP}(\mathrm{mm})$} & \multicolumn{4}{|c|}{$\operatorname{SOCD}(\mathrm{t} / \mathrm{ha})$} \\
\hline & $\min$ & median & $\max$ & average & $\min$ & median & $\max$ & average \\
\hline Cambisols & 11.85 & 39.60 & 46.25 & 38.69 & 16.77 & 27.54 & 46.82 & 27.83 \\
\hline Fluvisols & 34.59 & 38.84 & 46.72 & 39.81 & 15.81 & 21.14 & 31.85 & 23.29 \\
\hline
\end{tabular}

\section{Statistical Analyses}

Basic raw data processing was performed using Excel (Microsoft Corporation, USA) program. The programme Statistica 12 (StatSoft, Dell Software, USA) was used for statistical analyses. The potential differences in RP and SOCD were analysed using one-way analysis of variance together with posthoc Tukey's HSD test. Above all, the strength of a relationship between selected parameters was evaluated by correlation analysis. All analysis were performed at the level of significance $\mathrm{P}<0.05$.

\section{RESULTS AND DISCUSSION}

The results of the RP and SOCD in topsoil of arable land (Chernozems, Cambisols and Fluvisols) are stated in Tab. I.

The highest average RP of the study soils was found in Chernozems (40.17 mm). Nevertheless, the difference between the soil types is minimal and statistically insignificant $(\mathrm{P}>0.05)$. Although different soil types have different retention preconditions (Vlček et al., 2012; Chen et al., 2015), the significant difference was not confirmed. The result may point to the fact that intensive agricultural practices suppresses natural potential of the individual soil types in water retention and it leads to uniformity of this property.

Cambisols have the highest average value of SOCD (27.83 t/ha) and the biggest variation range. The difference between the individual soil types is minimal and statistically insignificant $(\mathrm{P}>0.05)$ there as well. However, according to FAO and CMCC (2017), the highest SOCDs (in 0-30 cm) should have been found in Chernozem (81.66 t/ha) followed by Cambisols (61.04 t/ha) and Fluvisols (39.34 t/ha). Therefore, it can be stated that longterm intensive agriculture and ploughing have led to oxidation of organic matter and poor diversity in the carbon stock of the individual soil types and to the disruption of the natural potential of the soil. It is similar as in the case of RP results. This finding is supported by the results of earlier studies where they state that SOC is greatly affected by agronomic practices (Xia et al., 2016) and intensive agronomic practices leads to a reduction in soil carbon (Manojlović et al., 2008).

Several studies may be used to compare the SOCD with other world agricultural soils. For example, Pan et al. (2003) reported a similar value for plow layer (about $15 \mathrm{~cm}$ ) in China, specifically $29.48 \mathrm{t} / \mathrm{ha}$.
$\mathrm{Xu}$ et al. (2011) reported a value of $47 \mathrm{t} / \mathrm{ha}$ in the depth of 0-10 cm of arable land in Ireland, which is twice higher than the average value of the studied Fluvisols. Such high value is related to a high rainfall and poor drainage. Chen et al. (2014) report SOCD $33.3 \mathrm{t} / \mathrm{ha}$ at cropland in China at the depth of 0-20 cm. Arrouays et al. (2002) state SOCD $<45$ t/ha in French soils $(0-30 \mathrm{~cm})$ of land under annual crops and perennial crops with bare soil. SOCD $32 \mathrm{t} / \mathrm{ha}$ in vineyards and crops with a very low organic return, and SOCD 43 t/ha in arable land have been found. SOCD less than $30 \mathrm{t} / \mathrm{ha}$ at a depth of $0-30 \mathrm{~cm}$ is considered as a low value for the croplands (Minasny et al., 2017). Since the depth of the studied profile is usually greater in the literature, and with increasing depth, the SOC decreases (Pan et al., 2003; FAO and CMCC, 2017), the mean values found in this study can be considered as average compared to the research studies.

The RP values (Tab. I) show a significant dispersion of data within individual soil types, which reflects the current state of arable land in Moravia. The RP minimal values of Cambisol and Chernozem are especially alarming. They were significantly below the average and indicate strong local degradation of the topsoil RP.

A similar situation is also observed at SOCD results. When focusing on individual soil types, the impact of different management is evident from the data dispersion (Fig. 1). For example, local application of ash in management have led to an above-average SOCD in Cambisols (46.82 t/ha).

The relation between RP and content of organic matter, SOCD respectively, is unusual in the framework of the monitored data. Although the literature frequently reports on significance of SOC for water retention (Hollis et al., 1977; Querejeta, 2017), its significant effect could not be confirmed in this study (Tab. II). Weak positive correlation between SOC and RP has been found only in Chernozems (0.57).

II: Correlation among soil retention potential, soil organic carbon and soil organic carbon density

\begin{tabular}{lccc}
\hline & RP & SOC & SOCD \\
\hline RP & 1 & & \\
SOC & 0.449 & 1 & \\
SOCD & 0.233 & 0.909 & 1 \\
\hline
\end{tabular}




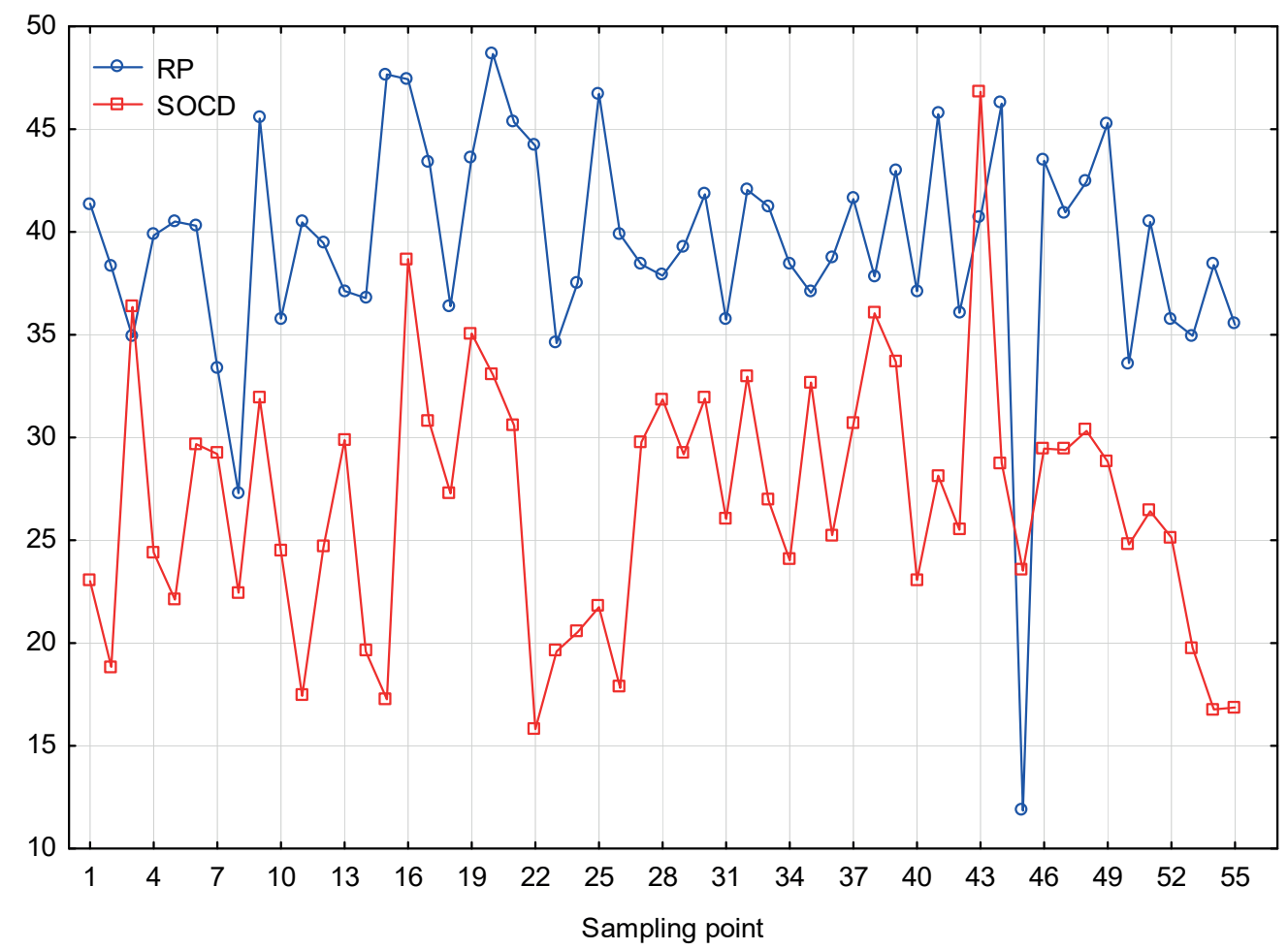

1: Comparison of RP and SOCD of the individual sampling sites

The finding is not entirely exceptional in scientific literature. Rawls et al. (2003) state in their review, that studies about the relationship between organic carbon content and soil water retention are often contradictory. They report on number of papers where amount of organic matter did not affect soil water retention significantly. Similarly, Minasny and McBratney (2018) state the increase in soil organic carbon has only a small effect on soil water retention.

Although, there is not confirmed statistically significant relation (Tab. II; $\mathrm{R}<0.5$ ) between $\mathrm{RP}$ and SOCD, Fig. 1 showed apparent similar trend of curves reflecting their very weak positive correlation. Insignificancy of their relation may be caused by agricultural practices leading to affection of other soil characteristics, which have not been studied but can have great effect on their relation. Such characteristics may be texture, which is a significant factor affecting relationship of soil water retention to organic carbon content (Rawls et al. 2003). No significant effect may point to possible unsuitability of the used formula to calculate potential retention (Vlček et al., 2012) as it is based on full water capacity.

\section{Management of Arable Land in Context of Climate Change}

The actual intensive agriculture can lead to increasing degradation of soil properties (Ulyett et al., 2014). It can be assumed that soil retention potential and carbon stock will be continuously reducing in future if the agricultural management does not change. In context of growing frequency of climatic extremes connected to climate change, mainly drought (Brázdil et al., 2015; Trnka et al., 2015; Štěpánek et al., 2016), the current agriculture production is unsustainable in long-term. More frequent and intense up to extreme precipitation, which is predicted for the future climate in the Czech Republic, will pose another risk of flash floods and landslides (Rulfová et al., 2017). Thus, agricultural management must change leading to increase retention potential and carbon stock, mainly in degraded soils (Minasny et al., 2017).

Increase of arable land carbon stock may be carried out by a range of procedures which can include atmospheric $\mathrm{CO}_{2}$ sequestration. These comprise, e.g. reduction in tillage disturbance, crop rotations, using cover crops, replacement of annual crops with perennial vegetation and growing deeprooted crops (Ogle et al., 2003; Manojlović et al., 2008; Minasny et al., 2017). One of the possible solutions is also biochar application (Ulyett et al., 2014; Wong et al., 2017). Increasing amount of soil organic matter combined with increased carbon stock (Ogle et al., 2003) will lead to reduction of atmospheric carbon and in degraded soil also to better retention potential which can mitigate climate change and its negative impacts (Hagemann et al., 2017; Minasny et al., 2017; Minasny and McBratney, 2018).

Although a number of the mentioned procedures has been applied to the studied arable lands, there is very strong decrease in RP and SOCD locally. 
Thus, it would be suitable to determine compulsory minimum limits of these parameters and to introduce them into the legislative. Adjustment of the agricultural practices will contribute to better non-production functions of soil. When principles of sustainable agriculture are complied, preserving of future production potential can be expected at simultaneous fulfilling non-production functions of the arable land.

\section{CONCLUSION}

The confirmed absence of difference between the studied Chernozems, Cambisols and Fluvisols in RP and SOCD points to the fact that long-term agriculture fades differences in particular soil types, in their water retention and carbon storage. SOCD of the studied soils is average in comparison to other agricultural lands.

Statistically significant correlation between the carbon stock and RP at the studied soils was not confirmed. It points to possibility, that their relationship is not on so high level and to possible strong effect of agricultural practices or to unsuitability of the retention potential formula.

In context of growing manifestation of the climate change, management of the arable land must be adjusted in order to increase carbon stock and soil water retention.

\section{Acknowledgements}

This research was supported by National Agency for Agricultural Research by project QK1720303 - Retention capacity of the soil and landscape and possibilities of increasing in terms of climate change (70\%), by project QK1920280 Innovation of the Evaluated Soil-Ecological Units (BPEJ) for state administration needs (20\%) and by project QK 1810233- Quantification of the impact of farming management on soil erosion, soil quality and yields of crops with proposals of the environmentally friendly cultivation technologies (10\%).

\section{REFERENCES}

ARROUAYS, D., BALESDENT, J., GERMON, J. C. et al. (Eds.). 2002. Mitigation of the greenhouse effect. Increasing carbon stocks in French agricultural soils? An assessment report compiled by the French Institute for Agricultural Research (INRA) on the request of the French Ministry for Ecology and Sustainable Development, Scientific Assessment Unit for Expertise. Paris, France: INRA.

BATJES, N. H. 1996. Development of a world data set of soil water retention properties using pedotransfer rules. Geoderma, 71(1-2): 31-52.

BERANOVÁ, R. and KYSELÝ, J. 2018. Trends of precipitation characteristics in the Czech Republic over 1961-2012, their spatial patterns and links to temperature and the North Atlantic Oscillation. International Journal of Climatology, 38: e596-e606.

BRÁZDIL, R., TRNKA, M., MIKŠOVSKÝ, J., ŘEZNÍČKOVÁ, L. and DOBROVOLNÝ, P. 2015. Spring-summer droughts in the Czech Land in 1805-2012 and their forcings. International Journal of Climatology, 35(7): 1405-1421.

CHEN, X. B., ZHENG, H., ZHANG, W., HE, X. Y., LI, L., WU, J. S. HUANG, D. Y. and SU, Y. R. 2014. Effects of land cover on soil organic carbon stock in a karst landscape with discontinuous soil distribution. Journal of Mountain Science, 11(3): 774-781.

CHEN, Y., LIU, R., BARRETT, D., GAO, L., ZHOU, M., RENZULLO, L. and EMELYANOVA, I. 2015. A spatial assessment framework for evaluating flood risk under extreme climates. Science of the Total Environment, 538: 512-523.

COLLENTINE, D. and FUTTER, M. N. 2018. Realising the potential of natural water retention measures in catchment flood management: Trade-offs and matching interests. Journal of Flood Risk Management, 11(1): 76-84.

ELBL, J., VAVERKOVÁ, M. D., ADAMCOVÁ, D., PLOŠEK, L., KINTL, A., LOŠÁK, T., HYNŠT, J. and KOTOVICOVÁ, J. 2015. Influence of fertilization on microbial activities, soil hydrophobicity and mineral nitrogen leaching. Ecological Chemistry and Engineering S, 21(4): 661-675.

FAO and CMCC. 2017. Global Soil Organic Carbon Database (at 30 arcsec). Rome: Food and Agriculture Organization of the United Nations and Euro-Mediterranean Center on Climate Change Foundation.

HAGEMANN, N., JOSEPH, S., SCHMIDT, H. P., KAMMANN, C. I., HARTER, J., BORCH, T., YOUNG, R. B., VARGA, K., TAHERYMOOSAVI, S., ELLIOTT, K. W. and MCKENNA, A. 2017. Organic coating on biochar explains its nutrient retention and stimulation of soil fertility. Nature communications, 8(1): 1089. 
HANEL, M., PAVLÁSKOVÁ, A. and KYSELÝ, J. 2016. Trends in characteristics of sub-daily heavy precipitation and rainfall erosivity in the Czech Republic. International Journal of Climatology, 36(4): 1833-1845.

HOLLIS, J. M., JONES, R. J. A. and PALMER, R. C. 1977. The effects of organic matter and particle size on the water-retention properties of some soils in the West Midlands of England. Geoderma, 17(3): 225-238.

ISO/TC 190/SC 3 COMMITTEE. 1998. Soil Quality - Determination of Organic Carbon by Sulfochromic Oxidation. ISO 14235. International Standards Office.

ISO/TC 190/SC 3 COMMITTEE. 2005. Soil Quality - Determination of pH. ISO 10390. International Standards Office.

KINTL, A., ELBL, J., LOŠÁK, T., VAVERKOVÁ, M. D. and NEDĚLNÍK, J. 2018. Mixed intercropping of wheat and white clover to enhance the sustainability of the conventional cropping system: effects on biomass production and leaching of mineral nitrogen. Sustainability, 10(10): 3367-3380.

KUBÁT, J., CERHANOVÁ, D., NOVÁKOVÁ, J., KLEMENT, V., ČERMÁK, P. and DOSTÁL, J. 2004. Total organic $\mathrm{C}$ and its decomposable part in arable soils in the Czech Republic. Archives of Agronomy and Soil Science, 50(1): 21-32.

LIU, R., WANG, M. and CHEN, W. 2018. The influence of urbanization on organic carbon sequestration and cycling in soils of Beijing. Landscape and Urban Planning, 169: 241-249.

MANOJLOVIĆ, M., AĆİN, V. and ŠEREMEŠIĆ, S. 2008. Long-term effects of agronomic practices on the soil organic carbon sequestration in Chernozem. Archives of Agronomy and Soil Science, 54(4): 353-367.

MIKHAILOVA, E. A. and POST, C. J. 2006. Organic carbon stocks in the Russian Chernozem. European Journal of Soil Science, 57(3): 330-336.

MINASNY, B. and MCBRATNEY, A. B. 2018. Limited effect of organic matter on soil available water capacity. European journal of soil science, 69(1): 39-47.

MiNASNY, B., MALONE B. P., MCBRATNEY, A. B., ANGERS, D. A., ARROUAYS, D., CHAMBERS, A., CHAPLOT, V., CHEN, Z. S., CHENG, K., DAS, B. S. and FIELD, D. J., 2017. Soil carbon 4 per mille. Geoderma, 292: 59-86.

OTALVARO, I. F., NETO, M. P. C., DELAGE, P. and CAICEDO, B. 2016. Relationship between soil structure and water retention properties in a residual compacted soil. Engineering geology, 205: 73-80.

PACHEPSKY, Y. A., TIMLIN, D. J. and RAWLS, W. J. 2001. Soil water retention as related to topographic variables. Soil Science Society of America Journal, 65(6): 1787-1795.

PACHEPSKY, Y. A., TIMLIN, D. J. and VARALLYAY G. Y. 1996. Artificial neural networks to estimate soil water retention from easily measurable data. Soil Science Society of America Journal, 60(3): 727-733.

PAN, G., LI, L., WU, L. and ZHANG, X. 2004. Storage and sequestration potential of topsoil organic carbon in China's paddy soils. Global Change Biology, 10(1): 79-92.

OGLE, S. M., JAY BREIDT, F., EVE, M. D. and PAUSTIAN, K. 2003. Uncertainty in estimating land use and management impacts on soil organic carbon storage for US agricultural lands between 1982 and 1997. Global Change Biology, 9(11): 1521-1542.

QUEREJETA, J. I. 2017. Soil water retention and availability as influenced by mycorrhizal symbiosis: consequences for individual plants, communities, and ecosystems. In: JOHNSON, N. (Ed.). Mycorrhizal Mediation of Soil. Elsevier, pp. 299-317.

RAWLS, W. J., PACHEPSKY, Y. A., RITCHIE, J. C., SOBECKI, T. M. and BLOODWORTH, H. 2003. Effect of soil organic carbon on soil water retention. Geoderma, 116(1-2): 61-76.

RUBIO, C. M., LLORENS, P. and GALLART, F. 2008. Uncertainty and efficiency of pedotransfer functions for estimating water retention characteristics of soils. European Journal of Soil Science, 59(2): 339347.

RULFOVÁ, Z., BERANOVÁ, R. and KYSELÝ, J. 2017. Climate change scenarios of convective and largescale precipitation in the Czech Republic based on EURO-CORDEX data. International Journal of Climatology, 37(5): 2451-2465.

ŠTĚPÁNEK, P., ZAHRADNÍČEK, P., FARDA, A., SKALÁK, P., TRNKA, M., MEITNER, J. and RAJDL, K. 2016. Projection of drought-inducing climate conditions in the Czech Republic according to EuroCORDEX models. Climate Research, 70(2-3): 179-193.

TRNKA, M., BRÁZDIL, R., MOŽNÝ, M., ŠTĚPÁNEK, P., DOBROVOLNÝ, P., ZAHRADNíČEK, P., BALEK, J., SEMERÁDOVÁ, D., DUBROVSKÝ, M., HLAVINKA, P. and EITZINGER, J. 2015. Soil moisture trends in the Czech Republic between 1961 and 2012. International Journal of Climatology, 35(13): 3733-3747.

ULYETT, J., SAKRABANI, R., KIBBLEWHITE, M. and HANN, M. 2014. Impact of biochar addition on water retention, nitrification and carbon dioxide evolution from two sandy loam soils. European Journal of Soil Science, 65(1): 96-104. 
VLČEK, L., KOCUM, J., JANSKÝ, B., ŠEFRNA, L. and KUČEROVÁ, A. 2012. Retention potential and hydrological balance of a peat bog: case study of Rokytka Moors, Otava River headwaters, sw. Czechia [in Czech: Retenční potenciál a hydrologická bilance horského vrchoviště: př́ípadová studie Rokytecké slatě, povodí horní Otavy, JZ. Česko]. Geografie, 117(4): 395-414.

WEBER, J., KARCZEWSKA, A., DROZD, J., LICZNAR, M., LICZNAR, S., JAMROZ, E. and KOCOWICZ, A. 2007. Agricultural and ecological aspects of a sandy soil as affected by the application of municipal solid waste composts. Soil Biology and Biochemistry, 39(6): 1294-1302.

WONG, J. T. F., CHEN, Z., CHEN, X., NG, C. W. W. and WONG, M. H. 2017. Soil-water retention behavior of compacted biochar-amended clay: a novel landfill final cover material. Journal of soils and sediments, 17(3): 590-598.

WÖSTEN, J. H. M., PACHEPSKY, Y. A. and RAWLS, W. J. 2001. Pedotransfer functions: bridging the gap between available basic soil data and missing soil hydraulic characteristics. Journal of hydrology, 251(3-4): 123-150.

XIA, L., XIA, Y., LI, B., WANG, J., WANG, S., ZHOU, W. and YAN, X. 2016. Integrating agronomic practices to reduce greenhouse gas emissions while increasing the economic return in a rice-based cropping system. Agriculture, Ecosystems \& Environment, 231: 24-33.

XU, X., LIU, W., ZHANG, C. and KIELY, G. 2011. Estimation of soil organic carbon stock and its spatial distribution in the Republic of Ireland. Soil Use and Management, 27(2): 156-162.

ZBÍRAL, J. 2016. Analysis of soils I.: Unified techniques [in Czech: Analýza půd I: Jednotné pracovní postupy]. $4^{\text {th }}$ Edition. Brno: Ústř̌ední kontrolní a zkušební ústav zemědělský.

Martin Brtnický: martin.brtnicky@seznam.cz

Václav Pecina: vaclav.pecina@mendelu.cz

Tereza Dokulilová: tereza.dokulilova@mendelu.cz

Jan Vopravil: vopravil.jan@vumop.cz

Tomáš Khel: khel.tomas@vumop.cz

Jan Zloch: jan.zloch@mendelu.cz

Vítězslav Vlček: vitezslav.vlcek@mendelu.cz 